\title{
Clinical experience with 5-aminosalicylate preparations in inflammatory bowel disease - A review
}

\begin{abstract}
The efficacy of 5-ASA tablets is around 65 to $70 \%$ in patients with active ulcerative colitis, whereas the efficacy of the rectal preparations approach $100 \%$ when the treatment is for active distal disease. When there is more extensive left sided colonic disease, the efficacy of 5-ASA rectal preparations is not as high, but it is still much improved over that seen with oral 5-ASA preparations. There is no data available for total colonic disease of either ulcerative colitis or Crohn's disease.

There is no controlled maintenance data available for Crohn's disease using 5-ASA preparations and no controlled or comparison data available for rectal preparations in Crohn's disease. There are no controlled dose-response studies of 5-ASA in patients with Crohn's disease. Thus, the most "therapeutic" dose is not known. The author's anecdotal evidence reports that patients with Crohn's disease affecting the rectum or left colon respond poorly to 5-ASA enemas. However, with continued use of more than six weeks at least a 50 to $60 \%$ response is seen. In contrast, virtually all patients with ulcerative proctitis respond by six weeks and all are controlled by 10 to 12 weeks.

When oral 5-ASA is compared with conventional oral sulfasalazine therapy, the efficacy is comparable. However, with 5-ASA the incidence of side effects is considerably lower; the number of patients discontinuing therapy is less; patient compliance is better, especially for the long term; dosage increase following inadequate action is more readily possible; and bacterial activation of the drug given is not necessary. Can J Gastroenterol 1987;1(1):28-32
\end{abstract}

Key Words: 5-Aminosalicylic acid (5-ASA), Crohn's disease, Oral (tablets), Rectal (enemas, suppositories), Ulcerative colitis, Ulcerative proctitis

Correspondence and reprints: Dr C.N. Williams, Division of Gastroenterology, Department of

Medicine, Dalhousie University. Halifax. Nova Scotia B3H 1 W2

Received for publication February, 1987. Accepted April 15, 1987
S ULFASALAZINE(SALAZOPYRINE: PHAR. macia) (1) is an azo compound compromised of two moieties; sulfapyridine and 5-aminosalicylic acid (5-ASA). Sulfapyridine acts as the vehicle and by its binding with 5-ASA prevents absorp. tion of 5-ASA in the small intestine. The active part is 5-ASA, released by bacterial cleavage in the colon (2). Sulfapyridine is associated with most of the side effects associated with sulfasalazine (3,4).

As of September 1986, there are two preparations in Canada of 5-ASA available on the market: Asacol (Norwich Eaton) $400 \mathrm{mg}$ tablets, and Salofalk (Interfalk) $4 \mathrm{~g}$ enemas. Other preparations available for investigative and compassionate use include Salofalk, $250 \mathrm{mg}$ tablets; Rowasa (Reid-Rowell, USA), 250 mg tablets; Pentasa (Ferring, Sweden), $250 \mathrm{mg}$ tablets and Dipentum (Pharmacia), $250 \mathrm{mg}$ tablets. Salofalk suppositories are available in 250 and $500 \mathrm{mg}$ size and Rowasa suppositories in $500 \mathrm{mg}$. Rowasa is also available as a $4 \mathrm{~g}$ enema. 
Slow release oral preparations include: Asacol, Salofalk, Rowasa and Pentasa. Asacol is coated with Eudragit-S, which enables the pill to be released above $\mathrm{pH}$ 7 in the colon, dissolution being slow at $\mathrm{pH} 2$ to 6 and 4 to $8 \mathrm{~h}$ at a $\mathrm{pH}$ of 7.5 . Salofalk, which is coated with ethylcellulose plus Eudragit- $\mathrm{L}$, is released at $\mathrm{pH}$ greater than 5.6 in the ileum and is dissolved in 1.5 to $2 \mathrm{~h}$ at $\mathrm{pH} 7.5$. Rowasa is similar to Salofalk, while Pentasa has an ethyl-cellulose covering only and is said to be available at any $\mathrm{pH}$. It should, therefore, be of particular use for treatment of Crohn's disease in the stomach and small intestine.

The 5-ASA oral preparations, which require colonic bacterial action for release of the active moiety, include Salazopyrine, which is 5-ASA and sulfapyridine; Dipentum, which is a dimer of two molecules of 5-ASA; and Polyasa, which is a dimer of 5-ASA and sulfanilamide ethylene polymer.

\section{SIDE EFFECTS}

The side effects of oral preparations of 5-ASA are infrequent and dose related, with headache, nausea, epigastric distress and diarrhea being the most common complaints. However, with salazopyrine, side effects are more frequent, up to $30 \%$ (5), are mainly dose related with occasional hypersensitivity reactions $(3,4)$. The side effects include anorexia, nausea, vomiting, epigastric distress, rash and rare reactions such as agranulocytosis, aplastic or hemolytic anemia, pancreatitis, drug-induced bloody diarthea $(6)$ and infertility $(7,8)$ being ascribed to hypersensitivity reactions.

Side effects of the rectal forms include occasional rectal soreness and possible hair loss and the initial inability to retain the 5-ASA suppositories and enemas. There are no readily available commercial preparations of sulfasalazine for rectal use at the present time.

Contraindications to 5-ASA therapy include: severe renal disease; severe liver disease; active peptic ulcer; and coagulopathies. Hypersensitivity reactions have been rarely described such as, drug rash, fever, bronchospasm and a lupus-like syndrome. Drug interactions are theoretically possible with sulphanylureas, coumarins, methotrexate, probenicid, spironolactone, furosamide and rifampin (manufacturer's safety suggestions).

\section{5-ASA USE}

5-ASA is useful in inflammatory bowel disease, both ulcerative colitis and Crohn's disease. Its use has been tested in the treatment of acute flare-ups of ulcerative colitis as well as in maintenance therapy, and for active Crohn's disease.

\section{ORAL PREPARATIONS}

Ulcerative colitis: In a two-week clinical trial (9), 13 of 20 patients given $2 \mathrm{~g} /$ day Dipentum for active ulcerative colitis improved, compared to eight of 20 patients given a placebo. One patient given Dipentum worsened compared to nine patients in the placebo group.

Salofalk ( $1.5 \mathrm{~g} /$ day) and sulfasalazine ( $3 \mathrm{~g} /$ day) were equally effective in controlling ulcerative colitis over eight weeks in 30 patients (10).

In an open trial of Polyasa ( $1.6 \mathrm{~g} /$ day for six weeks) seven of 10 patients clinically improved (11). No control data was available for treatment of ulcerative colitis with Polyasa.

Oral 5-ASA (Asacol $1.2 \mathrm{~g} /$ day) was compared with Salazopyrine (2 to 3 $\mathrm{g} /$ day) in the maintenance treatment of ulcerative colitis in 67 patients (12). Relapse at four months occurred in nine of $34(26 \%)$ taking Asacol and six of 33 $(18 \%$ ) taking salazopyrine (no significant difference). In a later report (12), seven of 32 patients $(22 \%)$ relapsed at six months on Asacol, $2.7 \mathrm{~g} /$ day, compared to five of $25(20 \%)$ taking salazopyrine, 2 to $3 \mathrm{~g} /$ day. In another open trial (13), the effect of Asacol alone, $2 \mathrm{~g} /$ day, in patients with ulcerative colitis was compared with a second group of patients who were more sick and required Asacol plus prednisone, 10 to $15 \mathrm{mg} /$ day. There were 19 patients in the first group and 12 patients in the second. Relapse occurred in two of $19(10 \%)$ with Asacol; and in five of $12(41 \%)$ with the drug combination.

Crohn's disease: Pentasa has been used at a dose of $1.5 \mathrm{~g} /$ day for 10 days in 12 patients with active Crohn's disease (14). There was no change in the Crohn's disease activity index (CDAI) versus placebo. In another study using Pentasa at $1.5 \mathrm{~g} /$ day or six weeks in 18 patients, the clinical condition of 13 patients improved while three worsened. The CDAI before treatment was 226 (normal, less than 150) and fell to 99 after treatment (15). In a double-blind study of oral 5ASA (Salofalk, $1.5 \mathrm{~g} /$ day) versus sulfasalazine ( $3 \mathrm{~g} /$ day), 13 of 15 patients taking 5-ASA and 12 of 15 patients taking sulfasalazine improved after eight weeks (10). In the group taking Salofalk, the CDAI before treatment was $308 \pm 72$ falling to $119 \pm 82$, $(\mathrm{P}<0.0001)$. In the group taking sulfasalazine the CDAI before treatment was $310 \pm 75$, dropping to $162 \pm$ $115(\mathrm{P}<0.0001)$ after treatment.

\section{RECTAL PREPARATIONS}

Suppositories: Salofalk suppositories ( $1.5 \mathrm{~g} /$ day) were used to treat 14 patients with ulcerative colitis and induced remission in $12(86 \%)$ after six weeks' therapy. In the same study using the parent compound, sulfasalazine, only seven of 11 patients $(64 \%)$ achieved remission in the same time frame. This is contrasted with one of seven patients taking sulfapyridine $(14 \%)$ who achieved remission over the six-week treatment period (16).

\section{TABLE 1}

Disease Activity Index: A qualitative rating derived by summing four categories

\begin{tabular}{|c|c|c|c|c|}
\hline \multirow[t]{2}{*}{ Category } & \multicolumn{4}{|c|}{ Score } \\
\hline & 0 & 1 & 2 & 3 \\
\hline $\begin{array}{l}\text { Evacuation } \\
\text { frequency }\end{array}$ & Normal & $\begin{array}{l}1-2 \text { more than } \\
\text { normal }\end{array}$ & $\begin{array}{l}3-4 \text { more than } \\
\text { normal }\end{array}$ & $\begin{array}{l}5+\text { more than } \\
\text { normal }\end{array}$ \\
\hline $\begin{array}{l}\text { Presence and } \\
\text { degree of rectal } \\
\text { bleeding }\end{array}$ & Normal & $\begin{array}{l}\text { Blood } \\
\text { occasionally }\end{array}$ & $\begin{array}{l}\text { Blood most } \\
\text { of the time }\end{array}$ & $\begin{array}{l}\text { Blood in all } \\
\text { evacuations }\end{array}$ \\
\hline $\begin{array}{l}\text { Mucosal appearance } \\
\text { on sigmoidoscopy }\end{array}$ & Normal & Mild & Moderate & Severe \\
\hline $\begin{array}{l}\text { Physician's overall } \\
\text { assessment }\end{array}$ & Normal & Mild & Moderate & Severe \\
\hline
\end{tabular}


In Canada, a group from Halifax and Toronto performed a double-blind. prospective, randomized, multicentre, placebo-controlled study of 5-ASA in the treatment of active distal proctitis (17). Criteria for entry included patients with $15 \mathrm{~cm}$, or less, of diffuse inflammation involving the rectum, who were either unresponsive to standard therapy, (sulfasalazine or steroid) or newly referred, untreated patients. The admission criteria included a disease activity score (DAl) of 3 or greater involving at least two of four categories (Table 1). The minimum score (normal) was 0 , the maximum score was 12. Patients were ambulatory, aged at least 18 years, having had no 4-ASA or 5-ASA within two days before entry and no rectal steroids within two weeks before entry. 5-ASA suppositories $(500 \mathrm{mg})$ or a placebo were used. three times a day, for six weeks. After six weeks, symptomatic patients were offered open active 5-ASA. If in remission, 5-ASA was offered to maintain remission and other drugs withdrawn. The minimum dose of 5-ASA suppository to maintain remission was sought.

There were eight men and six women in the active group and nine men and four women in the placebo group; mean age of $37.3 \pm 14.5$ and $42.7 \pm 11.2$ years, respectively. One male in the placebo group dropped out at three weeks and another male in the placebo group had salmonella and was excluded. There was no significant difference in the DAI between the two groups before treatment, $7.1 \pm 1.8$ active versus $7.4 \pm 1.8$ placebo groups (Table 2). However, there was a highly significant difference at three weeks, active group DAI $1.6 \pm 1.5$, placebogroup $5.8 \pm 1.9$ This did not increase in significance at six weeks, active group DAI 0.4 \pm 0.9 . placebo group $5.4 \pm 3.4$. The placebo group scores were not significantly different from the baseline value at three or six weeks.

There was an apparent sex difference in response; all the males in the active group had healed completely at six weeks, whereas three of the six women had improved significantly but were not completely healed. In a concurrent study (17). 5-ASA suppositories labelled with $99 \mathrm{~m}$ technetium were used and the appearances counted in a gamma counter over

TABLE 2

Effect of 5-ASA on the Disease Activity Index of patients with distal proctitis

\begin{tabular}{|c|c|c|c|c|c|c|c|}
\hline \multicolumn{4}{|c|}{ 5-ASA* } & \multicolumn{4}{|c|}{ Placebo } \\
\hline Sex & 0 weeks & 3 weeks & 6 weeks & Sex & 0 weeks & 3 weeks & 6 weeks \\
\hline Male & 9 & 3 & 0 & Male & 5 & 7 & 9 \\
\hline Male & 6 & 0 & 0 & Female & 12 & 7 & 9 \\
\hline Male & 9 & 3 & 0 & Male & 8 & 3 & 0 \\
\hline Femaie & 9 & 4 & 3 & Male & 5 & 5 & 3 \\
\hline Maie & 6 & 1 & 0 & Male & 7 & 8 & 6 \\
\hline Female & 7 & 4 & 0 & Male & 7 & 5 & 5 \\
\hline Female & 8 & 2 & 1 & Female & 8 & 6 & 10 \\
\hline Male & 5 & 2 & 0 & Female & 7 & 7 & 9 \\
\hline Female & 9 & 0 & 0 & Female & 8 & 4 & 3 \\
\hline Male & 6 & 0 & 0 & Male & 8 & 7 & - \\
\hline Male & 6 & 0 & 0 & Male & 7 & 2 & - \\
\hline Female & 5 & 2 & 0 & Male & 6 & 7 & 3 \\
\hline Male & 5 & 1 & 0 & Male & 8 & 8 & 2 \\
\hline Female & 10 & 0 & 2 & & & & \\
\hline \multirow[t]{2}{*}{ Mean $\pm S D$} & 7.14 & 1.57 & 0.43 & & 7.38 & 5.8 & 5.36 \\
\hline & \pm 1.8 & \pm 1.5 & \pm 0.94 & & \pm 1.8 & \pm 1.9 & \pm 3.4 \\
\hline
\end{tabular}

- $500 \mathrm{mg}$ suppositories three times a day.

a $6 \mathrm{~h}$ period to measure the extent of retrograde passage of the suppository. In patients with active, distal proctitis the rectum and sigmoid colon was covered adequately for $3 \mathrm{~h}$ after one suppository.

Figure $1 \mathrm{~A}$ shows representative histological changes of acute proctitis with crypt abscesses. In contrast, Figure 1B shows normal appearance of the rectum seen after six weeks of treatment with 5-ASA suppositories. The suppositories were safe, well tolerated, covered the area inflamed and were very effective.

In a separate study of patients with solitary ulcers of the rectum, symptoms disappeared completely when 5-ASA suppositories were given (18). The ulcers disappeared on sigmoidoscopy and biopsies confirmed this rapid resolution of pathology (Figures $2 \mathrm{~A}$ and $\mathrm{B}$ ).

Salofalk suppositories induced and maintained remission in virtually all patients with active ulcerative proctitis but only in $50 \%$ of patients with rectal Crohn's disease (19). In the Canadian study (20) the remission rate using 5-ASA suppositories alone was $18 \%$ at 26 weeks, comparable to any other form of treatment. The minimum dose necessary to achieve remission varied from one suppository at night to one suppository every second or third night.

Enemas: Sutherland and Martin (21) report that 5-ASA enemas, used in a prospective, placebo-controlled study in 153 patients with left sided and distal ulcerative colitis, were highly effective. There was no difference between the number of patients, the sex ratio, the age, the weight and the duration of the disease in the active and placebo group. or in the percentage of patients with the first episode, the baseline disease activity score in the males or females, or the use of concurrent medication. However, there were six "dropouts" in the 5-ASA group and 22 in the placebo group. This was related to offering active medication to those who were not responding at three weeks.

The physician rating of "much improved" showed a significant difference for males who responded better than females when each was compared to placebo. Twenty-two of 37 males responded positively to 5-ASA enemas compared to eight of 37 receiving placebo $(\mathrm{P}<$ 0.0001 ). The female response was 26 of 39 and 14 of 40 , respectively $(\mathrm{P}<0.06)$. This sex difference was, in part, related to the higher DAI for males before treatment, 8.43 versus 6.46 . The DAl of females was lower before treatment compared to the placebo female group 6.46 verus $7.65(\mathrm{P}<0.03)$.

In an Italian multicentre study (22), using $4 \mathrm{~g}$ 5-ASA or $100 \mathrm{mg}$ hydrocortisone enemas for 15 days in patients with left sided ulcerative colitis, there was clinical and microscopic improvement in 41 of $44(93 \%)$ in the 5-ASA group, compared to 24 of $42(57 \%)$ in the hydrocor- 

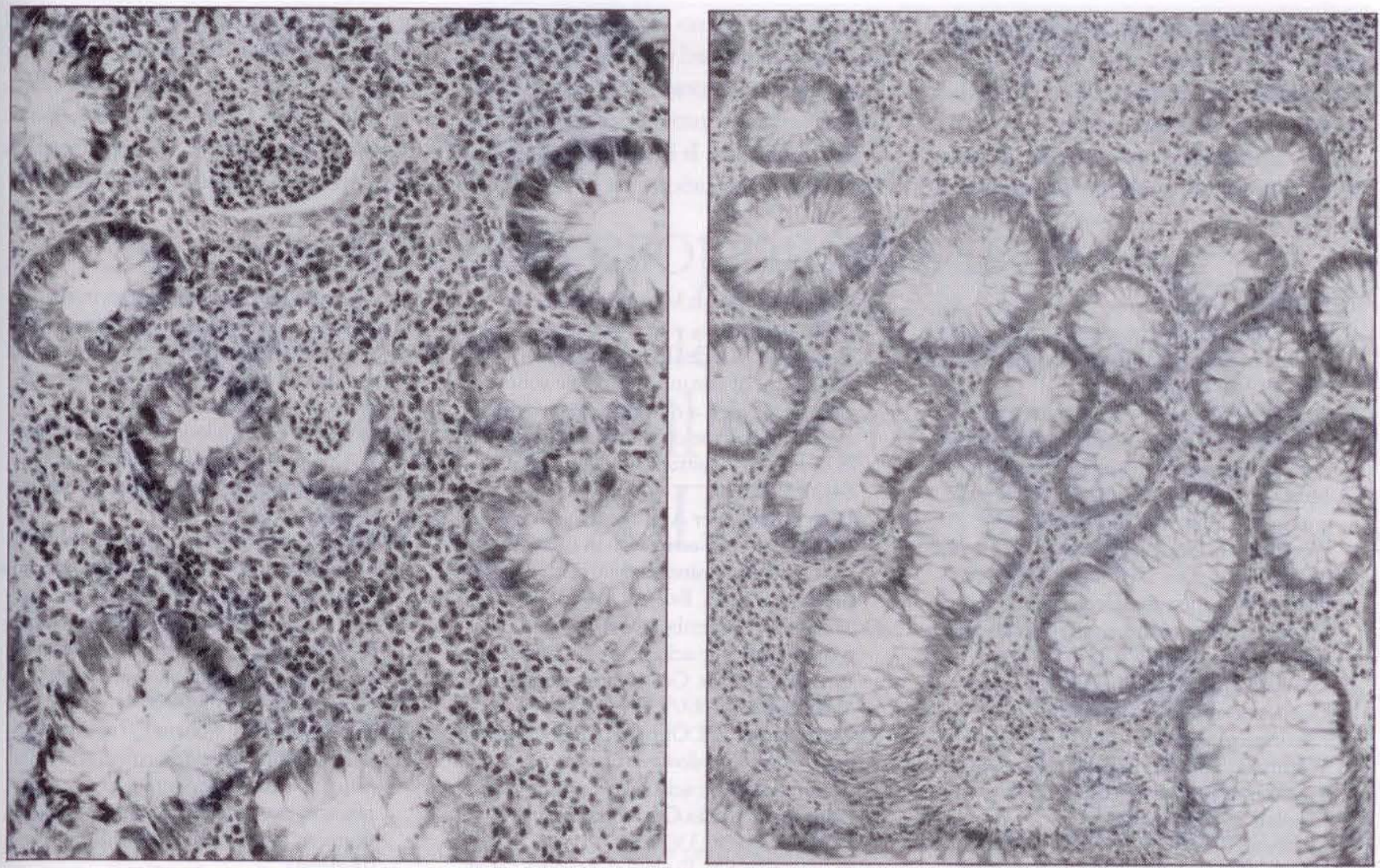

Figure 1A) (left) The appearances are typical for acute ulcerative proctitis. There is extensive inflammatory infiltrate with crypt abscesses. (B) (right) This shows tharthe inflammatory changes have subsided histologically, in keeping with normal sigmoidoscopy
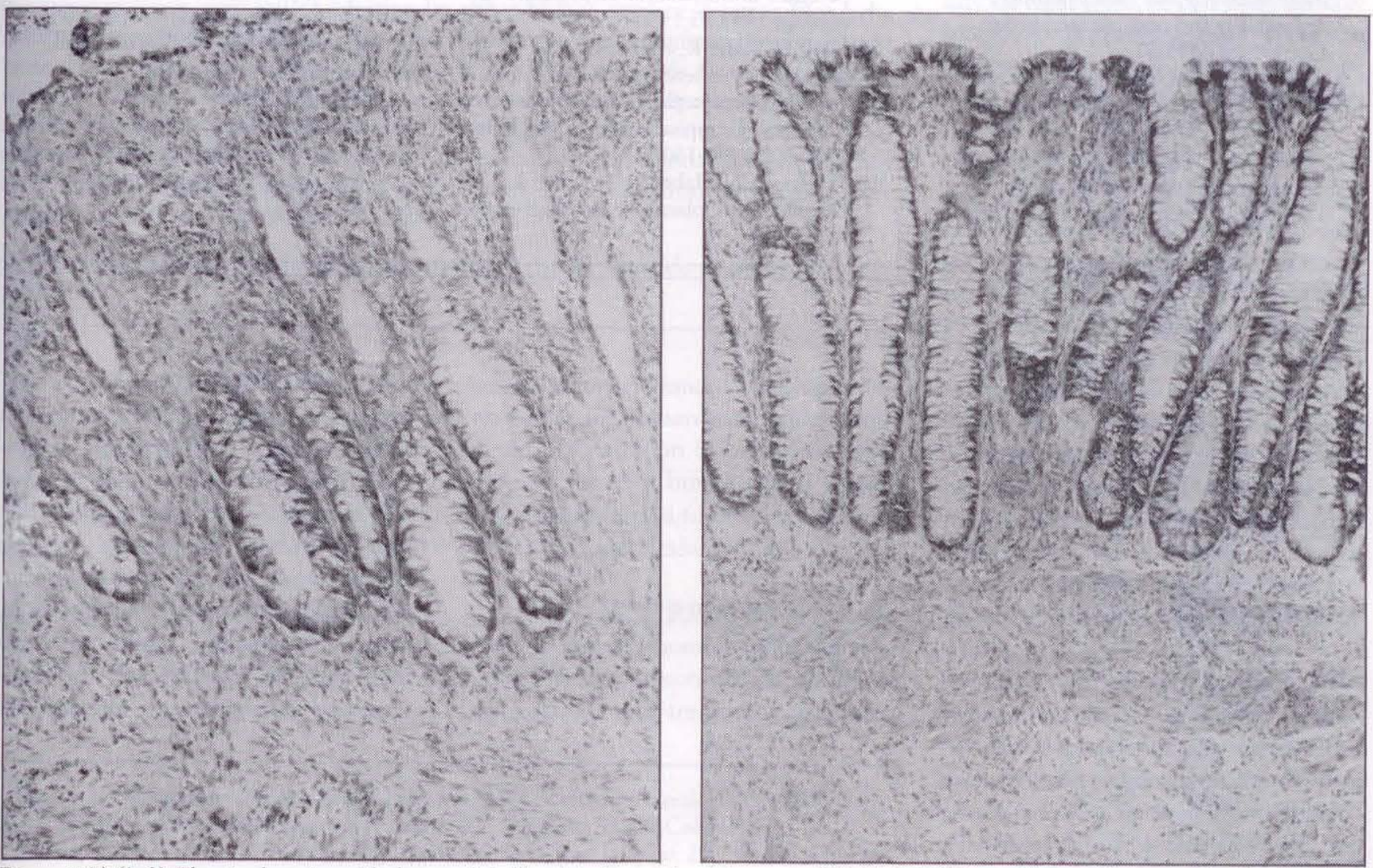

Figure 2A) (left) There is ulceration with characteristic fibrosis in the periglandular areas. (B) (right) This rectal biopsy taken six weeks after the biopsy from the same area shown in (A). There are no abnormal findings 
tisone group. Histologic improvement was seen in 34 patients $(77 \%)$ in the 5 ASA group and 23 patients $(53 \%)$ in the hydrocortisone-treated group.

In a controlled trial of patients with ulcerative colitis, olsalazine (Dipentum) was found to be no more effective than placebo when used rectally (23).

In conclusion, oral 5-ASA is indicated for sulfasalazine intolerance or hypersensitivity reactions. It is the author's belief that rectal preparations are the treatment of choice for distal ulcerative colitis and are effective when conventional therapy fails. When there is a slow or no effect, "think" rectal Crohn's disease. Rectal preparations of 5-ASA are useful in patients with "solitary" rectal ulcers.

\section{REFERENCES}

1. Svartz N. Salazopyrin, a new sulfanilamide preparation. Acta Med Scand 1942;110:57.

2. Azad Khan KA. An experiment to determine the active therapeutic moiety of sulphasalazine. Lancet 1977;ii:892-5.

3. Miller B. Nebenwirkungen der Therapie mit Salazosulfapyridin. Dtsch Med Worchensch 1980;105:1596-7.

4. Singleton JW, Law DH, Kelley MLJr, et al. National Cooperative Crohn's Disease Study: Adverse reactions to study drugs. Gastroenterology 1979;77:870-82.

5. Das KM, Dubin R. Clinical pharmacokinetics of sulphasalazine. Clin Pharmacokinet 1976; 1:406-25.

6. Werlin SL, Grand SJ. Bloody diarrhea a new complication of sulfasalazine. J Pediatr 1978;92:450-1.

7. Goldman P, Peppercorn MA. Sulfasalazine. N Engl ] Med 1975;2930:20-3.

8. Toovey SE, Hudson E. Hendry WF, et al. Sulphasalazine and male infertility: reversibility and possible mechanism. Gut 1981;22:445-51.

9. Selby WS, Barr GD, Ireland A, et al. Olsalazine in active ulcerative colitis. $\mathrm{Br}$ Med J 1985;291:1373-5.

10. Maier K et al. Erfolgreiche Akutbehandlung von chronisch entzundlichen Darmerkrankungen mitoraler 5-Aminos- alicylsaure. Dtsch Med Worchensch 1986;110:363-8.

11. Garetto M, Riddel RH, Winans CS. Treatment of chronic ulcerative colitis with Poly-ASA, a new non-absorbable carrier for release of 5-aminosalicylic acid in the colon. Gastroenterology 1983; $84(2): 1162$.

12. Dew MJ, Harrier AD, Evans N, et al. Maintenance of remission in ulcerative colitis with 5-aminosalicylic acid in high doses by mouth. Br Med] 1983;287:23-4

13. Habal FM, Greenberg GR. Oral 5-aminosalicylic acid in the treatment of ulcerative colitis. Gastroenterology 1985;88(2): 1409 .

14. Saverymutta SH, Gupta S, Keshavarzian A, et al. Effect of a slow release 5-aminosalicylic acid preparation on disease activity in Crohn's disease. Digestion 1986;33(2):89.

15. Rasmussen SN, Binder V, Maier K, et al. Treatment of Crohn's disease with peroral 5-aminosalicylic acid. Gastroenterology 1983;85:1350-3.

16. Klotz U, Maier K, Fischer C, et al. Therapeutic efficacy of sulfasalazine and its metabolites in patients with ulcerative colitis and Crohn's disease. N Engl J Med 1980;303:1499-1502.

17. Williams CN, Haber G, Aquino ]A. Double-blind, placebo-controlled evalu- ation of 5-ASA suppositories in the treatment of patients with active distal proctitis: measurement of extent of spread using $99 \mathrm{~m}$ Tc-5-ASA suppositories. Dig Dis Sci 1987. (In press)

18. Williams CN, Malatjalian D. The use of 5-ASA in patients with solitary rectal ulcers. Interfalk Canada Monograph, September 1987.

19. Maier K. Long-term prophylactic use of 5-ASA suppositories in colitis ulcerosa Verd Kranatheuten 1983;1:62-5.

20. Sidorov JJ, Williams CN. Open study of 5-ASA suppositories in ulcerative proctitis and ulcerative colitis. Clin Invest Med 1986;9:A60.

21. Sutherland LR, Martin F. Treatment of patients with left-sided colitis and distal proctitis with 5-ASA enemas, a placebo-controlled, prospective, randomized study. Dig Dis Sci, 1987. (In press)

22. Campieri M, Lanfranchi GA, Boschi S, et al. Topical administration of 5-aminosalicylic acid enemas in patients with ulcerative colitis: Studies on rectal absorption and secretion. Gut 1985;26:400-5.

23. Koch H. Azodisal sodium: a new treatment for inflammatory bowel disease. New Drugs, Pharmacy International, May 1985:111-2. 


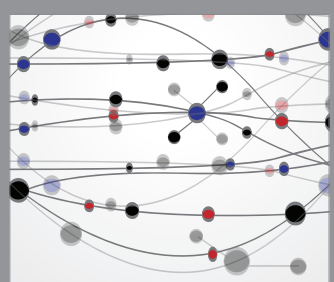

The Scientific World Journal
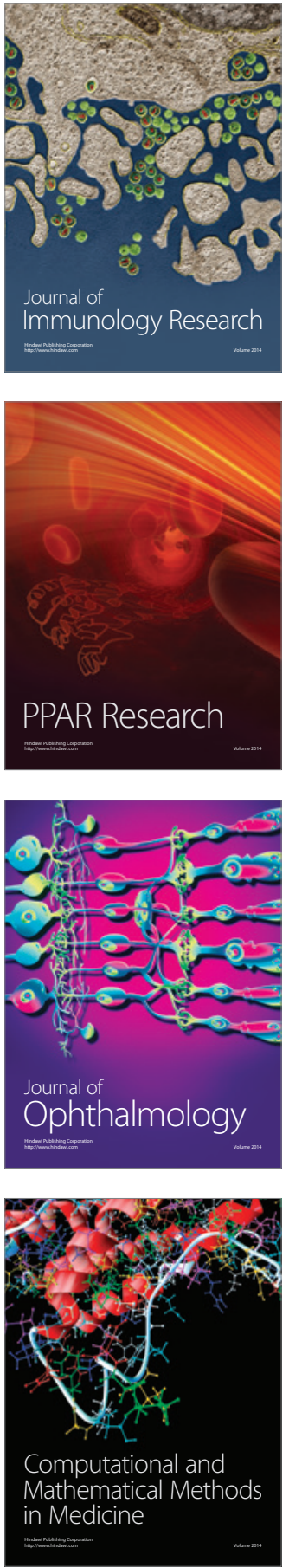

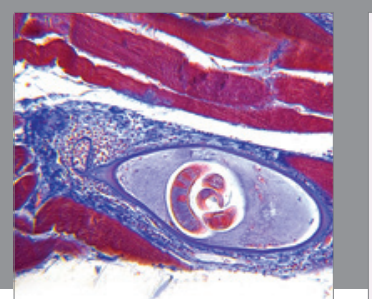

Gastroenterology Research and Practice

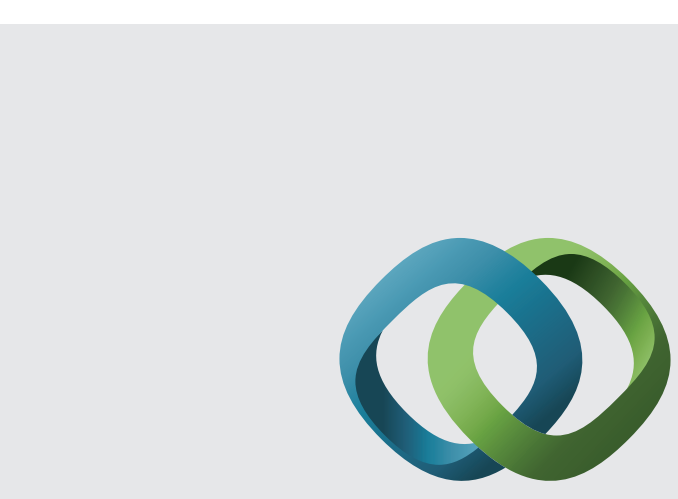

\section{Hindawi}

Submit your manuscripts at

http://www.hindawi.com
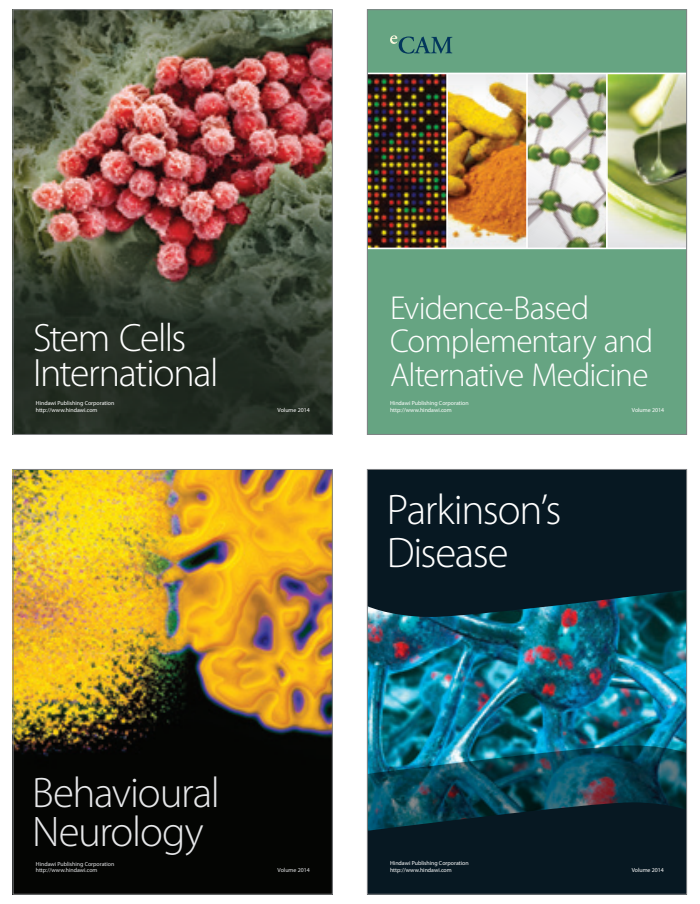
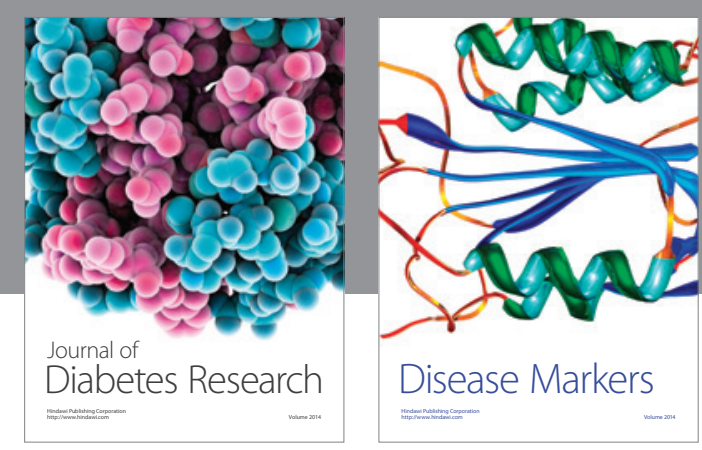

Disease Markers
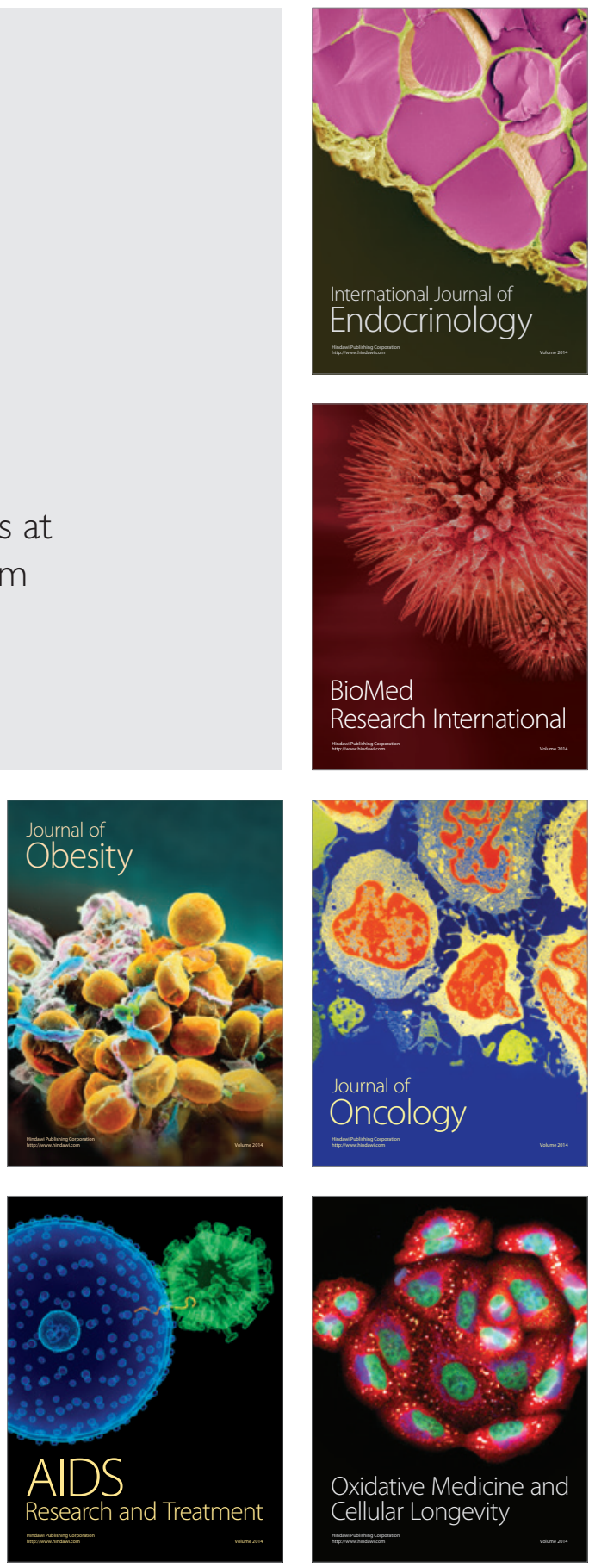